\title{
Arbuscular mycorrhizal fungi and mycorrhizal stimulant affect dry matter and nutrient accumulation in bean and soybean plants ${ }^{1}$
}

\author{
Fabrício Henrique Moreira Salgado ${ }^{2}$, Fatima Maria de Sousa Moreira ${ }^{3}$, \\ Helder Barbosa Paulino ${ }^{4}$, José Oswaldo Siqueira ${ }^{5}$, Marco Aurélio Carbone Carneiro ${ }^{2}$
}

\section{ABSTRACT}

The adoption of biological resources in agriculture may allow less dependence and better use of finite resources. This study aimed at evaluating the effects of inoculation with arbuscular mycorrhizal fungi native to the Brazilian Savannah associated with the application of mycorrhizal stimulant (7-hydroxy, 4'-methoxy-isoflavone), in the early growth of common bean and soybean. The experiment was carried out in a greenhouse, in a completely randomized design, with a $7 \times 2$ factorial arrangement, consisting of five arbuscular mycorrhizal fungi species, joint inoculation (junction of all species in equal proportions) and native fungi (without inoculation), in the presence and absence of stimulant. The following traits were evaluated: shoot dry matter, root dry matter, mycorrhizal colonization, nodules dry matter and accumulation of calcium, zinc and phosphorus in the shoot dry matter. The increase provided by the arbuscular mycorrhizal fungi and the use of stimulant reached over $200 \%$ in bean and over $80 \%$ in soybean plants. The fungi Acaulospora scrobiculata, Dentiscutata heterogama, Gigaspora margarita and Rhizophagus clarus, for bean, and Claroideoglomus etunicatum, Dentiscutata heterogama, Rhizophagus clarus and the joint inoculation, for soybean, increased the dry matter and nutrients accumulation.

KEYWORDS: Phaseolus vulgaris L.; Glicine max L.; formononetin.

\section{INTRODUCTION}

Arbuscular mycorrhizal fungi, which are important for plant communities, belong to the Glomeromycota phylum. They increase the absorption of water and nutrients by plants in the ecosystem (Moreira \& Siqueira 2006, Ferreira et al. 2012). Their primary role is to promote plant growth by improving its nutritional status, since they release their hyphae

\section{RESUMO}

Fungos micorrízicos arbusculares e estimulante micorrízico afetam a massa seca e o acúmulo de nutrientes em feijoeiro e soja

A adoção de recursos biológicos na agricultura pode permitir menor dependência e melhor aproveitamento de recursos finitos. Objetivou-se avaliar os efeitos da inoculação com fungos micorrízicos arbusculares nativos do Cerrado associados à aplicação de estimulante micorrízico (7-hidroxi, 4'-metoxi-isoflavona), no crescimento inicial de plantas de feijoeiro e soja. O experimento foi conduzido em casa-de-vegetação, em delineamento inteiramente casualizado e esquema fatorial 7 × 2 , sendo cinco espécies de fungos micorrízicos arbusculares, inoculação conjunta (junção de todas as espécies em igual proporção) e fungos nativos (sem inoculação), na presença e ausência de estimulante. Foram avaliados a massa seca da parte aérea, massa seca da raiz, colonização micorrízica, massa de nódulos e acúmulo de cálcio, zinco e fósforo na massa seca da parte aérea. $\mathrm{O}$ aumento proporcionado pelos fungos micorrízicos arbuculares e a utilização de estimulante chegou a mais de $200 \%$ no feijoeiro e a mais de $80 \%$ na soja. Os fungos Acaulospora scrobiculata, Dentiscutata heterogama, Gigaspora margarita e Rhizophagus clarus, para o feijoeiro, e Claroideoglomus etunicatus, Dentiscutata heterogama, Rhizophagus clarus e a inoculação conjunta, para a soja, se mostraram promissores no incremento de massa e acúmulo de nutrientes.

PALAVRAS-CHAVE: Phaseolus vulgaris L.; Glicine max L.; formononetina.

to explore the soil, providing a greater nutrient and water absorption to plants. This is of great importance for elements of low mobility in the soil that are beyond the root zone, such as phosphorus (Siqueira et al. 2002, Moreira \& Siqueira 2006, Marschner 2012). Thus, these soil microorganisms not only decrease the application of finite resources, such as fertilizers and water, but also provide their best use in the system (Fraser et al. 2009).

1. Manuscript received in Mar./2016 and accepted for publication in Oct./2016 (http://dx.doi.org/10.1590/1983-40632016v4640282).

2. Agência de Defesa Agropecuária do Estado do Tocantins, Gurupi, TO, Brazil.E-mail: fabriciogpi@hotmail.com.

3. Universidade Federal de Lavras, Departamento de Ciência do Solo, Lavras, MG, Brazil. E-mails: fmoreira@dcs.ufla.br, marcocarbone@dcs.ufla.br.

4. Universidade Federal de Goiás, Jataí, GO, Brazil.E-mail: heldelino51@yahoo.com.br.

5. Instituto Tecnológico Vale, Belém, PA, Brazil.E-mail: jose.oswaldo.siqueira@itv.org. 
However, the establishment of this symbiosis and the benefits from it depends on the relationship between fungi and plant species, which is modulated by biotic and abiotic soil factors (Siqueira et al. 2002, Moreira \& Siqueira 2006). Although there is no specificity between arbuscular mycorrhizal fungi and host plant, the soil management and use may cause changes in the diversity of native arbuscular mycorrhizal fungi (Ferreira et al. 2012) and select less efficient arbuscular mycorrhizal fungi, what will result in the need for greater input of fertilizers to maintain the crop yield. Therefore, it is important to know the diversity and the symbiotic and infective potential of native arbuscular mycorrhizal fungi in the Brazilian ecosystems, especially in the Brazilian Savannah biome (Cordeiro et al. 2015). However, for being obligate symbionts, the use of arbuscular mycorrhizal fungi has been limited, due to the high production cost of inoculants.

In the early 1990s, Nair et al. (1991) and Siqueira et al. (1991) found that some chemical substances were able to act as biochemical signals and as mycorrhizal colonization stimulants of native arbuscular mycorrhizal fungi, such as isoflavonoid formononetin (Nair et al. 1991, Siqueira et al. 1991). These stimulants are alternatives to maximize benefits in the nutritional improvement of plants and in the reduction of biotic and abiotic stresses. Thus, it is understood that formononetin stimulates the germination of arbuscular mycorrhizal fungi propagules, causing them to meet their symbiont (plant) and to start the symbiotic process earlier than it naturally occurs.

In Brazilian Savannah soils, the cultivation of common bean and soybean undergo some limitations, such as the low natural fertility of these soils and the occurrence of dry periods (about 15 to 20 days without rain). Techniques that mitigate these problems are extremely important for the best performance of these crops.

Cordeiro et al. (2015) demonstrated that the use of isoflavonoid formononetin provided a $50 \%$ increase in the colonization rate, as well as an increase of over $11 \%$ in the soybean production under drought conditions. Studies on isoflavones, such as formononetin, have been carried out over the years, such as that by Novais \& Siqueira (2009). However, the knowledge on its use, management, doses and association with propagules inoculation, among many other issues, still need to be clarified under Brazilian conditions.
Therefore, this study aimed at evaluating the effects of inoculation with native arbuscular mycorrhizal fungi from the Brazilian Savannah associated with the application of mycorrhizal stimulant (7-hydroxy, 4'-methoxy-isoflavone), in the initial growth of common bean and soybean plants.

\section{MATERIAL AND METHODS}

The experiment was carried out in a greenhouse, at the Univesidade Federal de Lavras, in Lavras, Minas Gerais State, Brazil, in a completely randomized design and a $7 \times 2$ factorial arrangement, with 5 arbuscular mycorrhizal fungi species, joint inoculation (all species in equal proportions) and native fungi (without inoculation), in the presence or absence of mycorrhizal stimulant, with 5 replications.

Arbuscular mycorrhizal fungi spores were collected in soils under Brazilian Savannah conditions $\left(17^{\circ} 56^{\prime} 35^{\prime \prime} \mathrm{S}, 51^{\circ} 43^{\prime} 38^{\prime \prime} \mathrm{W}\right.$ and $672 \mathrm{~m}$ of altitude). They were then isolated and identified as Acaulospora scrobiculata, Claroideoglomus etunicatum, Dentiscutata heterogama, Gigaspora margarita and Rhizophagus clarus. Each species was multiplied in culture pots, using Brachiaria brizantha as a host plant, for eight months.

The soil used in the study was an Oxisol collected on the subsurface layer (60-80 cm depth), corrected with dolomitic limestone and incubated for 30 days. Subsequently, it was chemical and physically characterized, as it follows: $\mathrm{pH}\left(\mathrm{H}_{2} \mathrm{O}\right)=$ $6.3 ; \mathrm{K}=12.00 \mathrm{mg} \mathrm{dm}^{-3} ; \mathrm{P}($ Mehlich1 $)=0.01 \mathrm{mg} \mathrm{dm}^{-3}$; $\mathrm{Ca}=2.10 \mathrm{cmol}_{\mathrm{c}} \mathrm{dm}^{-3} ; \mathrm{Mg}=0.50 \mathrm{cmol} \mathrm{dm}^{-3} ; \mathrm{Al}=$ $0.01 \mathrm{cmol}_{\mathrm{c}} \mathrm{dm}^{-3} ; \mathrm{H}+\mathrm{Al}=1.86 \mathrm{cmol}_{\mathrm{c}} \mathrm{dm}^{-3}$; clay $=$ $690 \mathrm{~g} \mathrm{~kg}^{1}$; silt $=140 \mathrm{~g} \mathrm{~kg}^{1}$; and sand $=170 \mathrm{~g} \mathrm{~kg}^{1}$. The density of native arbuscular mycorrhizal fungi spores in the soil was determined by wet sieving (Gerdemann \& Nicolson 1963), being found five unidentified arbuscular mycorrhizal fungi spores per $50 \mathrm{dm}^{-3}$ of soil.

Fertilization was carried out considering only $50 \%$ of the recommended $\mathrm{P}$ fertilization, by applying $40 \mathrm{~kg} \mathrm{ha}^{-1}$ of $\mathrm{N}, 60 \mathrm{~kg} \mathrm{ha} \mathrm{H}^{-1}$ of $\mathrm{P}_{2} \mathrm{O}_{5}$ and $60 \mathrm{~kg} \mathrm{ha}^{-1}$ of $\mathrm{K}_{2} \mathrm{O}$ for bean and $0 \mathrm{~kg} \mathrm{ha}^{-1}$ of $\mathrm{N}, 60 \mathrm{~kg} \mathrm{ha}^{-1}$ of $\mathrm{P}_{2} \mathrm{O}_{5}$ and $60 \mathrm{~kg} \mathrm{ha}^{-1}$ of $\mathrm{K}_{2} \mathrm{O}$ for soybean plants. The micronutrients zinc, magnesium, boron, copper, manganese and molybdenum were fertilized with the following doses: $2 \mathrm{~kg} \mathrm{ha}^{-1} ; 10 \mathrm{~kg} \mathrm{ha}^{-1} ; 0.01 \mathrm{~kg} \mathrm{ha}^{-1}$; $0.03 \mathrm{~kg} \mathrm{ha}^{-1} ; 1 \mathrm{~kg} \mathrm{ha}^{-1}$; and $0.02 \mathrm{~kg} \mathrm{ha}^{-1}$, respectively, for both crops (Sousa \& Lobato 2004). 
Seeds of Pérola cultivar were used for bean plants, while seeds of BMX Potência RR cultivar were used for soybean plants. Seeds were sterilized for 30 seconds in alcohol, 2 minutes in $2 \%$ sodium hypochlorite, and subsequently rinsed in sterile water. After disinfestation, they were subjected to the proposed treatments. The mycorrhizal stimulant formononetin (7-hydroxy, 4'-methoxy-isoflavone) was applied to the seeds, considering $0.9 \mathrm{~g} \mathrm{~kg}^{-1}$ of seeds. Soybean seeds were inoculated with the liquid inoculant Bradyrhizobium japonicum, strains SEMIA 5079 and 5080 , with $5 \times 10^{-9}$ of viable cells $\mathrm{mL}^{-1}$.

Sowing was carried out in August 2013, with three seeds sown in 3-kg pots. A total of $1 \mathrm{~mL}$ of the solution containing 100 spores of each arbuscular mycorrhizal fungi species was applied to each pot, except for the joint inoculation treatment, to which it was applied $1 \mathrm{~mL}$ of a solution containing equal proportions of all the arbuscular mycorrhizal fungi studied. Besides, $1 \mathrm{~mL}$ of the solution containing no spores was added to the control treatment.

Two bean and soybean plants were cultivated per pot. Humidity was maintained at $60 \%$ of the soil field capacity by periodic weighing and irrigation. The study was carried out up to the flowering stage, corresponding to 50 and 55 days for bean and soybean plants, respectively. Shoots and roots were collected, washed in distilled water, placed in paper bags and allowed to dry in a forced air circulation oven at $60{ }^{\circ} \mathrm{C}$, for $72 \mathrm{~h}$, when the shoot and root dry matter were obtained. Shoot dry matter was ground in a Wiley mill and digested in a nitropercloric solution, $\mathrm{P}$ levels were determined by colorimetry, and $\mathrm{Ca}$ and $\mathrm{Zn}$ levels were determined by atomic absorption spectrophotometry. All nutrients were determined following the methods described by Malavolta et al. (1997).

Before obtaining the soybean root dry matter, the nodules were weighed by removing them with a clamp. Bean plants showed no nodulation in their roots. Then, $1 \mathrm{~g}$ of fresh roots was collected, clarified with $\mathrm{KOH}$ and stained with methyl blue for the evaluation of mycorrhizal colonization (Giovannetti \& Mosse 1980).

The results were submitted to analysis of variance by applying the $\mathrm{F}$ test. Only the mycorrhizal colonization and nodules dry matter of soybean plants were transformed by the equation $(\mathrm{x}+0.5)^{0.5}$. The Scott-Knott test at $5 \%$ was applied for comparisons of treatments means, using the Sisvar software.

\section{RESULTS AND DISCUSSION}

In bean plants (Table 1), the arbuscular mycorrhizal fungi inoculation, alone or jointly, increased mycorrhizal colonization $(p \leq 0.05)$, both in the absence and in the presence of mycorrhizal stimulant. Mycorrhizal colonization varied according to the arbuscular mycorrhizal fungi species, and increments reached values up to $700 \%$ higher than those observed in the control without inoculation. The highest colonization rates $(\mathrm{p} \leq 0.05)$ were promoted by inoculation with $R$. clarus, or when there was joint inoculation of the five fungi species. In general, the arbuscular mycorrhizal fungi inoculation in bean plants, even in the absence of mycorrhizal stimulant, also reflected in increases in other

Table 1. Mycorrhizal colonization, shoot dry matter, root dry matter and accumulation of calcium, phosphorus and zinc in bean plants (Pérola cultivar), in function of inoculation with different arbuscular mycorrhizal fungi and application of mycorrhizal stimulant.

\begin{tabular}{|c|c|c|c|c|c|c|c|c|c|c|c|c|}
\hline \multirow{4}{*}{ Fungi } & \multirow{2}{*}{\multicolumn{2}{|c|}{$\begin{array}{c}\text { Colonization } \\
\% \\
\end{array}$}} & \multicolumn{2}{|c|}{ Shoot dry matter } & \multicolumn{2}{|c|}{ Root dry matter } & \multicolumn{2}{|c|}{$\mathrm{Ca}$} & \multicolumn{2}{|c|}{$\mathrm{P}$} & \multicolumn{2}{|c|}{$\mathrm{Zn}$} \\
\hline & & & \multicolumn{4}{|c|}{$\mathrm{g}$} & \multicolumn{4}{|c|}{$-\mathrm{mg}$} & \multicolumn{2}{|c|}{$-\mu \mathrm{g}-$} \\
\hline & \multicolumn{12}{|c|}{ Stimulant } \\
\hline & Without & With & Without & With & Without & With & Without & With & Without & With & Without & With \\
\hline Acaulospora scrobiculata & $26 \mathrm{eB}$ & $31 \mathrm{dA}$ & $2.31 \mathrm{bB}$ & $3.73 \mathrm{bA}$ & $0.47 \mathrm{bB}$ & $0.66 \mathrm{aA}$ & $22.2 \mathrm{bB}$ & $33.2 \mathrm{bA}$ & $3.0 \mathrm{bB}$ & $4.2 \mathrm{bA}$ & $79.1 \mathrm{cB}$ & $\overline{121.4 \mathrm{bA}}$ \\
\hline Claroideoglomus etunicatum & $24 \mathrm{eA}$ & $26 \mathrm{eA}$ & $1.81 \mathrm{cA}$ & $1.64 \mathrm{cA}$ & $0.42 \mathrm{bA}$ & $0.47 \mathrm{cA}$ & $21.6 \mathrm{bA}$ & $18.4 \mathrm{fB}$ & $2.9 \mathrm{bA}$ & $2.6 \mathrm{~dB}$ & $75.0 \mathrm{cA}$ & $75.9 \mathrm{eA}$ \\
\hline Dentiscutata heterogama & $32 \mathrm{dA}$ & $32 \mathrm{dA}$ & $1.69 \mathrm{cB}$ & $2.28 \mathrm{cA}$ & $0.56 \mathrm{aA}$ & $0.55 \mathrm{bA}$ & $20.5 \mathrm{bB}$ & $28.9 \mathrm{cA}$ & $2.3 \mathrm{cB}$ & $3.4 \mathrm{cA}$ & $86.0 \mathrm{bB}$ & $108.5 \mathrm{cA}$ \\
\hline Gigaspora margarita & $37 \mathrm{cA}$ & $35 \mathrm{cA}$ & $2.63 \mathrm{aB}$ & $4.06 \mathrm{aA}$ & $0.59 \mathrm{aA}$ & $0.45 \mathrm{cB}$ & $23.7 \mathrm{bB}$ & $38.6 \mathrm{aA}$ & $3.2 \mathrm{bB}$ & $4.9 \mathrm{aA}$ & $86.7 \mathrm{bB}$ & $153.3 \mathrm{aA}$ \\
\hline Rhizophagus clarus & $77 \mathrm{bA}$ & $67 \mathrm{aB}$ & $2.28 \mathrm{bA}$ & $2.21 \mathrm{cA}$ & $0.58 \mathrm{aA}$ & $0.40 \mathrm{cB}$ & $33.4 \mathrm{aA}$ & $24.2 \mathrm{~dB}$ & $3.5 \mathrm{aA}$ & $3.6 \mathrm{cA}$ & $110.9 \mathrm{aA}$ & $89.2 \mathrm{~dB}$ \\
\hline Joint inoculation & $83 \mathrm{aA}$ & $64 \mathrm{bB}$ & $1.61 \mathrm{cA}$ & $1.59 \mathrm{cA}$ & $0.55 \mathrm{aA}$ & $0.59 \mathrm{bA}$ & $22.4 \mathrm{bA}$ & $20.9 \mathrm{eA}$ & $2.1 \mathrm{~dB}$ & $2.6 \mathrm{dA}$ & $68.9 \mathrm{~dB}$ & $77.3 \mathrm{eA}$ \\
\hline Control & $11 \mathrm{fA}$ & $9 \mathrm{fB}$ & $1.68 \mathrm{cA}$ & $1.33 \mathrm{~dB}$ & $0.46 \mathrm{bB}$ & $0.56 \mathrm{bA}$ & $17.8 \mathrm{cA}$ & $15.4 \mathrm{gB}$ & $2.5 \mathrm{cA}$ & $2.4 \mathrm{dA}$ & $85.5 \mathrm{bA}$ & $86.5 \mathrm{dA}$ \\
\hline
\end{tabular}

Means followed by the same uppercase letter, in the row, and by the same lowercase letter, in the column, do not differ by the Scott-Knott test at $5 \%$. 
parameters evaluated, especially in shoot dry matter (G. margarita, A. scrobiculata and $R$. clarus), root dry matter (D. heterogama, G. margarita, $R$. clarus and joint inoculation) and in the accumulation of Ca (all treatments), P (R. clarus, A. scrobiculata, C. etunicatum and G. margarita) and $\mathrm{Zn}$ (R. clarus) (Table 1).

When comparing the effects of the mycorrhizal stimulant application, for each fungi species, both positive and negative effects were observed. The most consistent positive effects were observed in bean plants inoculated with $A$. scrobiculata. In this case, all the parameters presented significant increases ( $\mathrm{p} \leq 0.05$ ), for instance, increases of $\sim 17.3 \%$ in colonization, $61.5 \%$ in shoot dry matter, $40.4 \%$ in root dry matter, and $49.6 \%, 40.0 \%$ and $53.5 \%$ in the accumulation of $\mathrm{Ca}, \mathrm{P}$ and $\mathrm{Zn}$, respectively, when compared with native arbuscular mycorrhizal fungi. The use of mycorrhizal stimulant also promoted significant increases $(p \leq 0.05)$ in shoot dry matter (35-54 \%) and accumulation of $\mathrm{Ca}(40-62 \%)$, P (48-53\%) and Zn (26-77\%), in bean plants inoculated with $D$. heterogama and G. margarita, respectively, although effects of mycorrhizal stimulant on the colonization of these fungi were not observed. Bean plants inoculated with $R$. clarus, without mycorrhizal stimulant application, presented high colonization rates $(\sim 77 \%)$, what contributed to the highest root dry matter values and highest accumulation of $\mathrm{Ca}, \mathrm{P}$ and $\mathrm{Zn}$ among all treatments.

The joint inoculation of arbuscular mycorrhizal fungi increased the mycorrhizal colonization in bean plants. However, unlike observed for $R$. clarus, this high colonization rate did not contribute to increase the other parameters. In some cases, the values were similar to or lower than those observed in uninoculated plants.

The results show that the increase in the number of propagules by the arbuscular mycorrhizal fungi inoculation has positive effects on the development of bean plants. However, different arbuscular mycorrhizal fungi species differently contribute to plant growth and development. Since several studies have shown the absence of specificity among arbuscular mycorrhizal fungi and plant species, it can be concluded that the present results are mainly due to the physiological characteristics of each fungi species. In fact, species of rapid colonization, such as $R$. clarus, have advantages in short-cycle crops, such as bean. On the other hand, other arbuscular mycorrhizal fungi species, such as G. margarita, have slower colonization process.

Since bean plants present a short cycle (7595 days), when the flowering stage begins, there is a decrease in the displacement of photoassimilates to the roots, consequently affecting arbuscular mycorrhizal fungi species of slower colonization process. Despite this effect, it should also be considered that root colonization does not directly reflect the extent of the external mycelial network to the roots. In this case, even the roots with lower colonization rate may benefit from fungal species that are more efficient in the emission of external mycelium, consequently favoring the nutrient absorption.

Different responses were also observed with the use of mycorrhizal stimulating in other studies (Novais \& Siqueira 2009, Cordeiro et al 2015). However, the mycorrhizal colonization by native arbuscular mycorrhizal fungi was stimulated using the mycorrhizal stimulant (Cordeiro et al. 2015). This fact becomes important for the Brazilian Savannah region, for mycorrhizal plants have increased resistance to biotic (pests and diseases) and abiotic (water) stress, as several studies have shown (Novais \& Siqueira 2009, Ferreira et al. 2012, Cordeiro et al. 2015).

In the present study, it was observed that bean plants inoculated with all arbuscular mycorrhizal fungi together showed a higher contribution of mycorrhizal fungi, when compared to inoculation with only one species. This proves the important adoption of management practices and land use focusing on the increase of arbuscualr mycorrhizal fungi diversity in the soil, thus contributing to the increased growth of cultivated plants, as demonstrated in this study.

Soybean plants inoculated with the arbuscular mycorrhizal fungi $A$. scrobiculata, D. heterogama, $G$. margarita and $R$. clarus, as well as with joint inoculation, in the absence of mycorrhizal stimulant, presented higher colonization rates than the native mycorrhizal fungi (Table 2). When mycorrhizal stimulant was applied, except for D. heterogama and $R$. clarus, there was an increase in the colonization of soybean plants, even in the control treatment. The inoculation of arbuscular mycorrhizal fungi in soybean, in the absence of mycorrhizal stimulant, increased the shoot dry matter and accumulation of $\mathrm{Ca}$ (C. etunicatum and R. clarus), P (A. scrobiculata, 
C. etunicatum, D. heterogama and $R$. clarus) and Zn (A. scrobiculata, C. etunicatum and R. clarus), in relation to native arbuscular mycorrhizal fungi.

With the application of mycorrhizal stimulant, A. scrobiculata, C. etunicatum, D. heterogama, $R$. clarus and the joint inoculation significantly increased $(\mathrm{p} \leq 0.05)$ the shoot dry matter, and $C$. etunicatum, D. heterogama and the joint inoculation also increased the accumulation of $\mathrm{Ca}$, providing better results, in relation to native arbuscular mycorrhizal fungi.

When comparing the results for soybean (Table 2), it was observed that the association between the arbuscular mycorrhizal fungi inoculation and the use of mycorrhizal stimulant is beneficial to all arbuscular mycorrhizal fungi and to native mycorrhizal fungi. However, there were variations according to the mycorrhizal fungi species and the evaluated trait.

Inoculation with arbuscular mycorrhizal fungi in the absence of mycorrhizal stimulant promoted an increase of more than $29 \%$ in shoot dry matter, $3 \%$ in root dry matter, $14 \%$ in the accumulation of $\mathrm{Ca}, 35 \%$ in $\mathrm{P}$, and $90 \%$ in $\mathrm{Zn}$, when compared with native arbuscular mycorrhizal fungi. In the presence of mycorrhizal stimulant, the inoculation with arbuscular mycorrhizal fungi promoted an increase of more than $26 \%$ in shoot dry matter, $85 \%$ in root dry matter, $31 \%$ in $\mathrm{Ca}$ and $4 \%$ in $\mathrm{P}$.

Variations in nodules dry matter were observed in plants, according to the fungal species. The highest values occurred in the presence of D. heterogama in joint inoculation or in native fungi (Figure 1). However, nodules dry matter does not necessarily have a direct relationship with the efficiency of symbiotic nitrogen fixation. In this study, the soybean nodules dry matter of plants inoculated with $C$. etunicatum, A. scrobiculata and $R$. clarus was extremely low. Despite that, these species were the ones that promoted greater gains in shoot dry matter and in the accumulation of $\mathrm{Ca}, \mathrm{P}$ and $\mathrm{Zn}$, surpassing the values observed for D. heterogama, joint inoculation or for the control, which showed a greater nodules dry matter.

Leguminous plants, such as soybean, may establish tripartite symbiosis with nitrogen-fixing bacteria and mycorrhizal fungi. In this association, the plant transfers carbon compounds to bacteria and

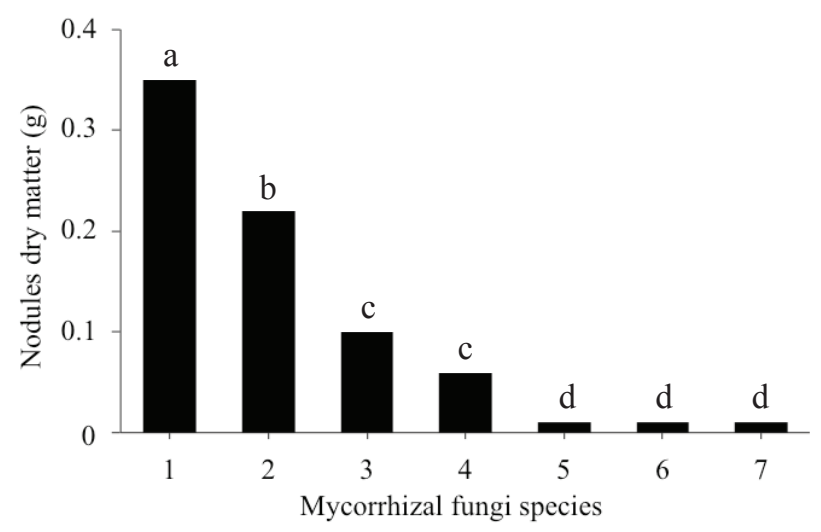

Figure 1. Nodules dry matter of soybean cultived in an Oxisol, in the presence and absence of mycorrhizal stimulant. 1 - joint inoculation; 2 - Dentiscutata heterogama; 3 - control; 4 - Gigaspora margarita; 5 - Claroideoglomus etunicatum; 6 - Acaulospora scrobiculata; 7 - Rhizophagus clarus. Equal lowercase letters do not differ by the Scott-Knott test at $5 \%$.

Table 2. Mycorrhizal colonization, shoot dry matter, root dry matter and accumulation of calcium, phosphorus and zinc in soybean plants (BMX Potência RR cultivar), in function of inoculation with different arbuscular mycorrhizal fungi and application of mycorrhizal stimulant.

\begin{tabular}{|c|c|c|c|c|c|c|c|c|c|c|c|c|}
\hline \multirow{4}{*}{ Fungi } & \multirow{2}{*}{\multicolumn{2}{|c|}{$\begin{array}{c}\text { Colonization } \\
\% \\
\end{array}$}} & \multicolumn{2}{|c|}{ Shoot dry matter } & \multicolumn{2}{|c|}{ Root dry matter } & \multicolumn{2}{|c|}{$\mathrm{Ca}$} & \multicolumn{2}{|l|}{$\mathrm{P}$} & \multicolumn{2}{|c|}{$\mathrm{Zn}$} \\
\hline & & & \multicolumn{4}{|c|}{$\mathrm{g}$} & \multicolumn{4}{|c|}{$\mathrm{mg}$} & \multicolumn{2}{|c|}{$-\mu \mathrm{g}-$} \\
\hline & \multicolumn{12}{|c|}{ Stimulant } \\
\hline & Without & With & Without & With & Without & With & Without & With & Without & With & Without & With \\
\hline Acaulospora scrobiculata & $53 \mathrm{aA}$ & $49 \mathrm{cA}$ & $2.38 \mathrm{cB}$ & $2.59 \mathrm{bA}$ & $0.14 \mathrm{~dB}$ & $0.21 \mathrm{eA}$ & $25.6 \mathrm{cA}$ & $20.7 \mathrm{cB}$ & $1.9 \mathrm{cA}$ & $2.0 \mathrm{bA}$ & $106.5 \mathrm{aA}$ & $85.9 \mathrm{aB}$ \\
\hline Claroideoglomus etunicatum & $37 \mathrm{cB}$ & $78 \mathrm{aA}$ & $2.92 \mathrm{aA}$ & $2.84 \mathrm{aA}$ & $0.35 \mathrm{cB}$ & $0.40 \mathrm{cA}$ & $27.9 \mathrm{aA}$ & $26.9 \mathrm{aA}$ & $2.3 \mathrm{aA}$ & $2.4 \mathrm{aA}$ & $79.9 \mathrm{bA}$ & $74.4 \mathrm{bA}$ \\
\hline Dentiscutata heterogama & $45 \mathrm{bA}$ & $36 \mathrm{eB}$ & $2.46 \mathrm{cB}$ & $2.63 \mathrm{bA}$ & $0.55 \mathrm{bA}$ & $0.53 \mathrm{bA}$ & $24.3 \mathrm{cA}$ & $22.7 \mathrm{bB}$ & $1.8 \mathrm{cB}$ & $2.1 \mathrm{bA}$ & $54.1 \mathrm{cB}$ & $68.0 \mathrm{bA}$ \\
\hline Gigaspora margarita & $53 \mathrm{aB}$ & $74 \mathrm{aA}$ & $2.31 \mathrm{cA}$ & $2.15 \mathrm{~dB}$ & $0.52 \mathrm{bA}$ & $0.35 \mathrm{~dB}$ & $21.9 \mathrm{dA}$ & $18.1 \mathrm{~dB}$ & $1.9 \mathrm{cA}$ & $1.8 \mathrm{bA}$ & $66.8 \mathrm{cA}$ & $48.3 \mathrm{cB}$ \\
\hline Rhizophagus clarus & $45 \mathrm{bA}$ & $34 \mathrm{eB}$ & $2.86 \mathrm{bA}$ & $2.45 \mathrm{cB}$ & $0.21 \mathrm{cA}$ & $0.19 \mathrm{eA}$ & $26.2 \mathrm{bA}$ & $21.1 \mathrm{cB}$ & $2.1 \mathrm{bA}$ & $1.9 \mathrm{bA}$ & $76.6 \mathrm{bA}$ & $70.1 \mathrm{bA}$ \\
\hline Joint inoculation & $45 \mathrm{bB}$ & $62 \mathrm{bA}$ & $1.71 \mathrm{~dB}$ & $2.46 \mathrm{cA}$ & $0.61 \mathrm{aA}$ & $0.63 \mathrm{aA}$ & $19.1 \mathrm{eB}$ & $23.8 \mathrm{bA}$ & $1.5 \mathrm{~dB}$ & $2.0 \mathrm{bA}$ & $55.3 \mathrm{cB}$ & $68.2 \mathrm{bA}$ \\
\hline Control & $34 \mathrm{cB}$ & $40 \mathrm{dA}$ & $2.26 \mathrm{cA}$ & $2.25 \mathrm{dA}$ & $0.59 \mathrm{aA}$ & $0.34 \mathrm{~dB}$ & $24.5 \mathrm{cA}$ & $20.5 \mathrm{cB}$ & $1.7 \mathrm{~dB}$ & $2.3 \mathrm{aA}$ & $56.1 \mathrm{cB}$ & $97.6 \mathrm{aA}$ \\
\hline
\end{tabular}

Means followed by the same uppercase letter, in the row, and by the same lowercase letter, in the column, do not differ by the Scott-Knott test at $5 \%$. 
fungi present in the roots, by means of photosynthesis. The bacteria, in turn, increase the $\mathrm{N}$ content, by means of biological fixation of atmospheric $\mathrm{N}_{2}$, and the arbuscular mycorrhizal fungi contribute primarily to $\mathrm{P}$ intake. However, the simultaneous presence of symbionts may result in synergistic, neutral or even antagonistic effects for the development of the host plant, depending on the bacteria and arbuscular mycorrhizal fungi species (Azcón et al. 1991, Ahmad 1995, Xavier \& Germida 2002, Silva et al. 2016).

In this study, the inoculation of nitrogen-fixing bacteria in soybean may have contributed to increase the mycorrhizal colonization rate, since the mean values of this parameter were much higher than those observed in common bean plants, especially for the control treatment (Table 1).

Responses to the use of mycorrhizal fungi are wide (Hetrick et al. 1996), with great influence of soil fertility (Moreira \& Siqueira 2006) and combination of host plant genotypes and arbuscular mycorrhizal fungi (Baum et al. 2009), although there was no specificity (Moreira \& Siqueira 2006, Siqueira et al. 2010).

The use of inocula and chemical substances that stimulate the mycorrhiza association are among the strategies of arbuscular mycorrhizal fungi use as biotechnological resources in agriculture (Siqueira et al. 2002, Silva et al. 2016). In the first case, the goal is to increase the number of propagules, so there is a greater possibility of symbiosis (Abbott \& Robson 1991). In the second one, the goal is to accelerate the symbiotic process of the native community or of the inoculated arbuscular mycorrhizal fungi (Siqueira et al. 2002).

In most cases, treatments promoted higher mycorrhizal colonization than the native arbuscular mycorrhizal fungi. However, the success of the association should not be restricted to the evaluation of this trait (Hetrick et al. 1996), and it is more appropriate to verify whether there was an increase in dry matter and/or in the nutrient accumulation in plants (Smith \& Smith 2011). As observed in soybean, some arbuscular mycorrhizal fungi did not promote a greater mycorrhizal colonization than native fungi. However, they were able to increase the dry matter and nutrient content. The same colonization rate may provide different results (Smith \& Smith 2011).

In the present study, it was observed a variation in the response, in relation to the arbuscular mycorrhizal fungi species used, corroborating the study by Wang et al. (2008), which showed that different arbuscular mycorrhizal fungi species provide different results. These results ranged from gain provided by Glomus mosseae to no effect with Glomus intraradices, in the same genotype (Wang et al. 2008). It also corroborates the results obtained by Tobar et al. (1994), in which an arbuscular mycorrhizal fungi species may favor a greater absorption of a given element, while another species may favor a greater absorption of another element.

Thus, besides the identification of the benefits promoted by arbuscular mycorrhizal fungi, species capable of providing the highest gains as possible should be identified. Therefore, selection should favor not only those which provide an increase in dry matter or in nutrient content (Smith \& Smith 2011), in order to indicate the best combinations to the various agro-ecosystems (Richardson 2009), since the identification of fungi, in a given agricultural system, is a challenge (Smith \& Smith 2011).

Thus, A. scrobiculata, G. margarita and $R$. clarus in common bean plants, and C. etunicatum and $R$. clarus in soybean plants, proved to be promising when inoculated. On the other hand, when associated with mycorrhizal stimulant, A. scrobiculata, D. heterogama and G. margarita in bean plants, as well as C. etunicatum, D. heterogama and joint inoculation in soybean plants, proved to be promising.

\section{CONCLUSIONS}

1. Responses to inoculation with arbuscular mycorrhizal fungi and to the use of colonization stimulant varied with the arbuscular mycorrhizal fungi species, for both Phaseulus vulgaris and Glycine max plants;

2. Acaulospora scrobiculata, Dentiscutata heterogama, Gigaspora margarita and Rhizophagus clarus for bean plants, and Claroideoglomus etunicatum, Dentiscutata heterogama, Rhizophagus clarus and joint inoculation for soybean plants, increased shoot dry matter and nutrients accumulation.

\section{REFERENCES}

ABBOTT, L. K.; ROBSON, A. D. Field management of VA mycorrhizal fungi. In: KEISTER, D. L.; CREGAN, P. 
B. (Eds.). The rhizosphere and plant growth. Dordrecht: Kluwer Academic Publishers, 1991. p. 355-362.

AHMAD, M. H. Compatibility and coselection of vesicular-arbuscular mycorrhizal fungi and Rhizobia for tropical legumes. Critical Reviews in Biotechnology, v. 15, n. 3-4, p. 229-239, 1995.

AZCÓN, R.; RUBIO, R.; BAREA, J. M. Selective interactions between different species of mycorrhizal fungi and Rhizobium meliloti strains, and their effects on growth, $\mathrm{N}_{2}$-fixation (15N) and nutrition of Medicago sativa L. New Phytologist, v. 117, n. 3, p. 399-404, 1991.

BAUM, C. et al. The significance of host-fungus combinations in ectomycorrhizal symbioses for the chemical quality of willow foliage. Plant and Soil, v. 323, n. 1-2, p. 213-224, 2009.

CORDEIRO, M. A. S. et al. Mycorrhization stimulant based in formononetin associated to fungicide and doses of phosphorus in soybean in the Cerrado. Bioscience Journal, v. 31, n. 4, p. 1062-1070, 2015.

FERREIRA, D. A.; CARNEIRO, M. A. C.; SAGGIN JÚNIOR, O. J. Fungos micorrízicos arbusculares em um Latossolo Vermelho sob manejos e usos no Cerrado. Revista Brasileira de Ciência do Solo, v. 36, n. 1, p. 5161, 2012.

FRASER, T. et al. Arbuscular mycorrhiza: where nature and industry meet. In: KHASA, D.; PICHÉ, Y.; COUGHLAN, A. P. (Eds.). Advances in mycorrhizal science and technology. Ottawa: NRC Research Press, 2009. p. 71-86.

GERDEMANN, J. W.; NICOLSON, T. H. Spores of mycorrhizal endogone species extracted from spil by wet-sieving and decanting. Transactions of the British Mycological Society, v. 46, n. 2, p. 235-244, 1963.

GIOVANNETTI, M.; MOSSE, B. An evaluation of techniques to measure vesicular-arbuscular mycorrhizal infection in roots. New Phytologist, v. 84, n. 3, p. 489500, 1980.

HETRICK, B. A. D.; WILSON, G. W. T.; TODD, T. C. Mycorrhizal response in wheat cultivars: relationship to phosphorus. Canadian Journal of Botany, v. 74, n. 1, p. 19-25, 1996.

MALAVOLTA, E.; VITTI, G. C.; OLIVEIRA, S. A. Avaliação do estado nutricional das plantas: princípios e aplicações. Piracicaba: Associação Brasileira para a Pesquisa da Potassa e do Fosfato, 1997.

MARSCHNER, P. Rhizosphere biology. In: MARSCHNER, P. (Ed.). Mineral nutrition of higher plants. 3. ed. London: Elsevier, 2012. p. 369-388.
MOREIRA, F. M. S.; SIQUEIRA, J. O. Microbiologia e bioquímica do solo. 2. ed. Lavras: UFLa, 2006.

NAIR, M. G.; SAFIR, G. R.; SIQUEIRA, J. O. Isolation and identification of vesicular-arbuscular mycorrhizastimulatory compounds from clover (Trifolium repens) roots. Applied and Environmental Microbiology, v. 57, n. 2, p. 434-439, 1991.

NOVAIS, C. B.; SIQUEIRA, J. O. Aplicação de formononetina na colonização e esporulação de fungos micorrízicos em braquiária. Pesquisa Agropecuária Brasileira, v. 44, n. 5, p. 496-502, 2009.

RICHARDSON, A. E. Regulating the phosphorus nutrition of plants: molecular biology meeting agronomic needs. Plant and Soil, v. 322, n. 1-2, p. 17-24, 2009.

SILVA, J. S. da et al. Formononetin stimulates mycorrhizal fungi colonization on the surface of active root nodules in soybean. Symbiosis, p. 1-8, 2016.

SIQUEIRA, J. O. et al. Micorrizas: 30 anos de pesquisas no Brasil. Lavras: UFLa, 2010.

SIQUEIRA, J. O.; LAMBAIS, M. R.; STÜRMER, S. L. Fungos micorrízicos arbusculares: características, associação simbiótica e aplicação na agricultura. Biotecnologia, Ciência e Desenvolvimento, v. 25, n. 1, p. 12-21, 2002.

SIQUEIRA, J. O.; SAFIR, G. R.; NAIR, M. G. Stimulation of vesicular-arbuscular mycorrhiza formation and growth of white clover by flavonoid compounds. New Phytologist, v. 118, n. 1, p. 87-93, 1991.

SMITH, F. A.; SMITH, S. E. What is the significance of the arbuscular mycorrhizal colonisation of many economically important crop plants? Plant and Soil, v. 348, n. 1-2, p. 63-79, 2011.

SOUSA, D. M. G.; LOBATO, E. Cerrado: correção do solo e adubação. Brasília, DF: Embrapa Informação Tecnológica, 2004.

TOBAR, R. M.; AZCÓN, R.; BAREA, J. M. The improvement of plant $\mathrm{N}$ acquisition from an ammoniumtreated, drought-stressed soil by the fungal symbiont in arbuscular mycorrhizae. Mycorrhiza, v. 4, n. 3, p. 105108, 1994.

WANG, C. X. et al. Effects of arbuscular mycorrhizal fungi on growth and yield of cucumber plants. Communications in Soil Science and Plant Analysis, v. 39, n. 3-4, p. 499509, 2008.

XAVIER, L. J. C. ; GERMIDA, J. J. Response of lentil under controlled conditions to co-inoculation with arbuscular mycorrhizal fungi and rhizobia varying in efficacy. Soil Biology and Biochemistry, v. 34, n. 2, p. 181-188, 2002. 